\title{
PENGEMBANGAN KREATIVITAS ANAK USIA DINI MELALUI PERMAINAN EDUKATIF
}

\author{
Siti Hairiyah \\ STIT Al-Karimiyyah Sumenep \\ Mukhlis \\ STIT Al-Karimiyyah Sumenep
}

\begin{abstract}
Kreatifitas perlu dikembangkan semaksimal mungkin karena dalam memperkaya pemikiran seorang anak, segala ide yang ada pada diri anak akan dapat dikembangkan melalui aktifitas kreatif. Aktifitas kreatif memberikan kesempatan untuk mengekspresikan perasan adan pikiran seseorang, untuk mengembangkan kreatifitas pada diri anak guru dituntut untuk mendemonstrasikan dan menunjukkan proses kreatifitas. Pendidikan anak usia dini berperan penting dalam membantu perkembangan anak dan pembentukan kepribadiannya. Pembelajaran pada anak usia dini menggunakan pripsip belajar sambil bermain, dengan demikian permainanpemainan yang digunakan selama proses pembelajaran sebaiknya dapat bernilai pendidikan agar dapat mencapai tujuan yang diinginkan dalam pembelajaran. Oleh karena itu permainan yang digunakan seorang guru di sekolah harus diperhatikan sebaik mungkin agar dapat membantu aspekaspek perkembangan anak, karena tidak semua permainan dapat digunakan dalam pembelajaran. Pendidik anak usia dini harus menunjukkan kemampuan kreatifitasnya dalam setiap pembelajaran agar anak-anak didiknya dapat menunjukkan pula kemampuan dirinya, permainan edukatif harus selalu dikembangkan baik di sekolah atau di rumah agar dapat membantu pengembangan kreatifitas seorang anak khususnya pada pendidikan anak usia dini dan diharapkan dapat mendorong untuk menjadi kreatif.
\end{abstract}

Keywords: Kreatifitas, Anak usia dini, Permainan edukatif

Kariman, Volume 07, Nomor 02, Desember 2019|265 
Siti Hairiyah \& Mukhlis

\section{Latar Belakang}

Pengembangan kreativitas sangatlah penting untuk dilakukan sedini mungkin agar tercipta kepribadian yang baik pada anak. Anak adalah penerus bangsa, anak bukanlah kertas kosong tetapi ia adalah pribadi yang aktif untuk menjadi kreatif dengan hal itulah maka perkembangan anak perlu diperhatikan dari sejak lahir sampai seterusnya. Sangatlah penting melakukan upaya pembinaan yang ditujukan kepada anak sejak lahir sampai dengan usia enam tahun dalam bentuk pemberian rangsangan pendidikan untuk membantu pertumbuhan dan perkembangan jasmani dan rohani agar anak memiliki kesiapan dalam memasuki kehidupan selanjutnya.

Menurut Syamsu perkembangan anak pra-sekolah itu meliputi sembilan perkembangan; perkembangan fisik, perkembangan intelektual, perkembangan emosional, perkembangan bahasa, perkembangan sosial, perkembangan bermain, perkembangan kepribadian, perkembangan moral, dan perkembangan kesadaran beragama. ${ }^{1}$

Bermain adalah berbuat sesuatu untuk menyenangkan hati, baik menggunakan alat permainan atau tidak. ${ }^{2}$ Bermain bagi anak usia dini dapat mempelajari dan belajar banyak hal, mengenal banyak aturan, bersosialisasi, menempatkan diri, menata emosi, toleransi, kerja sama, dan menjunjung tinggi sportivitas. Aktivitas bermain juga dapat mengembangkan kecerdasan mental, spiritual, Bahasa, dan keterampilan motoric anak, dengan demikian maka bermain merupakan kegiatan pembelajaran yang sangat penting.

Pentingnya permainan bagi berbagai aspek perkembangan anak usia dini secara umum berdasarkan pada empat teori; Pertama Herbert Spencer, ia berasumsi bahwa anak bermain karena mereka punya energy berlebih, energy ini mendorong mereka untuk melakukan aktifitas sehingga mereka terbebas dari perasaan tertekan. Kedua Moritz Lazarus; ia berasumsi bahwa anak bermain karena mereka memerlukan penyegaran kembali atau mengembalikan energy yang habis digunakan u/ kegiatan rutin sehari". Ketiga Erikson; ia berasumsi bahwa anak bermain akan membantu mengembangkan rasa harga diri, karena dengan bermain anak pemperoleh kemampuan untuk menguasai tubuh mereka, mengusai dan memahami benda-benda serta belajar keterampilan social. Keempat Sigmund

\footnotetext{
${ }^{1}$ Syamsu Yusuf LN, Psikologi Perkembangan Anak \& Remaja, (Bandung: PT Remaja Rosdakarya, 2014), hlm. 163177.

${ }^{2}$ Dadan Suryana, Nenny Mahyudin, Dasar-Dasar Pendidikan TK, ( Tangerang selatan: Universitas Terbuka, 2014), hlm. 4.1
}

266 | Kariman, Volume 07, Nomor 02, Desember 2019 
Freud; ia berasumsi lewat kaca mata psikoanalitis, sehingga disebut teori psikoanalitis. Asumsinya anak bermain merupakan suatu mekanisme untuk mengulang kembali peristiwa traumatic yang dialami sebelumnya sebagai upaya untuk memperbaiki atau menguasai pengalaman tersebut demi kepuasan anak.

Bermain sangat penting bagi anak usia dini karena melalui bermain dapat mengembangkan aspek-aspek perkembangan anak, dan jika anak tumbuh dan berkembang dengan maksimal maka anak akan lebih percaya diri, meiliki rasa nyaman, dan memiliki konsep diri yang positif. ${ }^{3}$ Selain kita melihat beberapa asumsi tentang teori bermain, kita juga dapat melihat dari pengaruh bermain. Sebagaimana Hurlock mengatakan bahwa pengaruh bermain bagi perkembangan anak meliputi sembilan hal diantaranya adalah; Perkembangan fisik, dorongan berkomunikasi, penyaluran emosional yang terpendam, Penyaluran dari keinginan dan kebutuhan yang tidak terpenuhi, sumber belajar, rangsangan kreatifitas, belajar bersosialisasi, belajar standart moral, dan mengembangkan kepribadian. ${ }^{4}$

Akan tetapi walaupun permainan itu sangat penting dalam berbagai aspek perkembangan anak usia dini, tidak semua permainan dapat di gunakan. Dalam hal ini untuk mengembangkan kreativitas anak usia dini diperlukan yang namanya permainan edukatif. Alat Permainan Edukatif adalah segala sesuatu yang dapat digunakan sebagai sarana atau peralatan untuk bermain yang mengandung nilai edukatif (pendidikan) dan dapat mengembangkan seluruh kemampuan anak. Menurut Badru Zaman Alat Permainan Edukatif adalah permainan yang sengaja dirancang secara khusus untuk kepentingan pendidikan. ${ }^{5}$

\section{Pengembangan Kreatifitas}

Pengembangan atau perkembangan merupakan serangkaian perubahan yang berlangsung secara terus menerus dan bersifat tetap dari fungsi- fungsi jasmaniah dan rohaniah yang dimiliki individu menuju ke tahap kematangan melalui pertumbuhan, pemasakan, dan belajar. ${ }^{6}$ Menurut E. de. Bono kreatifitas adalah keterampilan yang dapat dipelajari, dikembangkan, dan diterapkan, serta digunakan oleh semua orang. Keterampilan tersebut sama seperti bermain bermain ski, bermain tenis, memasak, atau belajar matematika. Semua orang

\footnotetext{
${ }^{3}$ Mohammad Fauziddin, Pembelajaran PAUD Bermain, Cerita, dan Menyanyi Secara Islami, (Bandung: PT REmaja Rosdakarya, 2014), hlm. 15.

${ }^{4}$ Hibana S Rahman, Konsep Dasar Pendidikan Anak Usia Dini, (Yogyakarta: PGTKI Press, 2005), hlm. 85-87.

${ }^{5}$ Badru Zaman, dalam https:/www.asik belajar.com (diakses tgl 20 November 2019), hlm.1.

${ }^{6}$ Desmita, Psikologi Perkembangan Peserta Didik Panduan Bagi Orang Tua dan Guru Dalam Memahami Psikologi Anak Usia SD, SMP, dan SMA, (Bandung: PT Remaja Rosdakarya, 2014)hlm.9.
} 
Siti Hairiyah \& Mukhlis

dapat mempelajari keterampilan semacam itu, akan tetapi pada ahirnya tidak semua orang bisa menguasai keterampilan tersebut dengan sama baiknya. Hal ini ditunjukkan oleh adanya perbedaan-perbedaan kemampuan seseorang dalam segala hal. ${ }^{7}$

Dengan demikian dapat difahami bahwa pengembangan atau perkembangan adalah perubahan sesuatu yang menunjukkan pada hal-hal yang baru, dari hari kehari mengalami kemajuan. Seorang anak dapat dilihat perkembangannya melalui peubahan-perubahan yang dilaluinya, yang tentunya perubahan tersebut adalah perubahan ke arah yang positif. Anak dapat dikatakan berkembang jika melewati beberapa perubahan, dari yang awalnya tidak tahu berubah menjadi tahu, dari yang awalnya tidak bisa berubah menjadi bisa, dan lain-lain.

Kreatifitas adalah kemampuan untuk berkreasi atau daya untuk mencipta. ${ }^{8}$ Menurut Nurla Isna Aunillah kreatifitas adalah kemampuan seseorang dalam memunculkan atau menciptakan sesuatu yang baru, berdasarkan pengalaman, wawasan, maupun hubungannya dengan orang lain dan lingkungan. Semiawan dalam Munandar (2004) berpendapat bahwa kreatifitas ini dapat dilihat pada proses berfikir saat seseorang memecahkan masalah; ${ }^{9}$ pertama, berupa kemampuan dalam memberikan jawaban dan mengemukakan pendapat atau ide-ide. Kedua, berupa kemampuan untuk mengemukakan berbagai alternatif dalam memecahkan masalah. Ketiga, berupa kemampuan untuk menghasilkan berbagai hasil karya yang merupakan pemikiran sendiri. Keempat, berupa kemampuan untuk memperluas ide dan aspek-aspek yang yang mungkin tidak terfikirkan atau terlihat oleh orang lain.

Kreatifitas seorang anak dapat diketahui oleh orang tua dalam kehidupannya sehari-hari karena orang tua lah yang selalu bersama anak dalam kesehariannya. Anak kreatif atau tidak dapat dipantau oleh orang tua mulai dari sejak lahir, seorang anak kecil tentu tidak dapat beraktifitas seperti orang tua dengan demikian maka kreatif tidaknya seorang anak dapat dilihat dari hal yang terkecil. Misalnya pada saat bermain, seorang anak yang kreatif dia bisa berkreasi menjadikan sapu sebagai kuda lalu dinaiki, sementara anak yang tidak kreatif dia hanya diam saja.

\footnotetext{
${ }^{7}$ E. de. Bono, Metode Mencetuskan Ide-Ide Cerdas, Orisinal, dan Kreatif, (Jogjakarta: tHink, 2008), hlm. 9.

${ }^{8}$ Pius A Partanto dan M Dahlan Al Barry, Kamus Ilmiah Populer, (Surabaya: Arkola, 2001), hlm.377.

${ }^{9}$ Yuliani Nurani Sujiono. Dkk, Metode Pengembangan Kognitif, (Tangerang Selatan: Universitas Terbuka,2013), hlm. 11.4.
} 
Seorang anak kreatif atau tidak dapat diketahui oleh orang tua sejak kecil, karena orang tua yang selalu bersama anak dalam kehidupannya sehari dengan begitu orang tua dapat mengetahui kegiatan anak. Dalam hal ini orang tua bisa mencocokkan kenyataan diri anak dengan ciri-ciri anak kreatif menurut pandangan ahli, sebagaimana pernyataan Nurla Isna Aulillah yang menyebutkan setidaknya terdapat 6 ciri-ciri anak yang kreatif:; ${ }^{10}$ Berfikir lancar, fleksibel dalam berfikir, senang menjajaki lingkungannya, banyak mengajukan pertanyaan, rasa ingin tahunya tinggi, dan berminat melakukan banyak hal.

Dari beberapa pernyataan diatas tentang ciri-ciri anak kreatif dapat difahami bahwa kreatifitas anak dapat dilihat dari berbagai aspek; Pertama, kognitif yakni kemampuan untuk menangkap dan mengerti suatu masalah, kelancaran dalam berfikir, fleksibilitas, orisinalitas, redefinsi, dan elaborasi. Kedua, afektif yakni minat yang luas, bebas dalam berfikir, selalu ingin tahu, mempunyai inisiatif, selalu ingin mendapatkan pengalaman-pengalaman baru, percaya diri, berani mengambil resiko, dan mempunyai daya imajinasi yang kuat. ${ }^{11}$

Langkah-langkah yang perlu dilakukan untuk menumbuhkan kreativitas anak; Jangan terlalu mendikte, membatasi, dan melarang kreativitas anak, jangan membatasi ide anak, jangan terbiasa mengejek dan mencela hasil kerja anak, jangan menakut-nakuti anak, jangan membenci keinginan si kecil melakukan sesuatu, berikan tantangan kepada anak, dan sering-seringlah memberikan pilihan kepada anak. ${ }^{12}$

Sebagai orang tua di rumah tentunya memiliki peran penting dalam mengembangkan segala aspek perkembangan anak, hal ini disebabkan karena waktu orang tua bersama anak lebih banyak. Agar aspek perkembangan anak dapat berkembang dengan baik maka orang tua hendaknya membantu secara bijak, pada saat anak bermain berikan waktu sepenuhnya, biarkan ia bermain sesuka hatinya dan sesuai dengan ide-idenya, sebagai orang tua cukup memantau dari jauh. Kalaupun anak melakukan suatu permainan yang salah maka orang tua tidak perlu menyalahkannya, karena sesuatu yang benar menurut orang tua belum tentu benar menurut anak, pemikiran dan imajinasi anak dengan orang tua tidak sama.

\footnotetext{
${ }^{10}$ Nurla Isna Aunillah, Membentuk Karakter Anak, (Yogyakarta: FlashBooks, 2015), hlm, 72-75

${ }^{11}$ Kak Seto, Bermain dan Kreatifitas, (Jakarta: Papas Sinar Sinanti, 2004), hlm.20-22.

${ }^{12}$ Ibid, Nurla, hlm. 90.
} 
Siti Hairiyah \& Mukhlis

Menurut Joan Freeman ada empat kegiatan yang dapat dilakukan untuk mengembangkan kreatifitas. ${ }^{13}$ Pertama, melatih pengindraan, melatih motorik halus dan kasar, wisata kreatif, serta meningkatkan kesadaran dan penerimaan diri, dan kerjasama, dengan membuat bentuk lukisan badan sendiri.

Terdapat banyak hal yang dapat menghambat perkembangan kreatifitas anak, diantaranya adalah; ${ }^{14}$ Orang tua yang kurang memberi dukungan pada anak baik dalam hal materi atau pemikiran, ruang yang diberikan untuk bermain terlalu sedikit padahal bermain meberikan pelajaran yang cukup berarti bagi anak dan juga dengan bermain anak akan dapat mengembangkan kreatifitasnya karena saat bermain anak bebas memilih dan bebas bereksplorasi. Sebagaimana menurut Nurla Faktor-faktor yang menghambat kreatifitas anak; Kurangnya motivasi, jadwal yang ketat, terlalu menekankan kebersamaan dengan keluarga, terlalu bersifat konservatif, dan penyediaan alat permainan yang terlalu terstruktur.

\section{Anak Usia Dini}

Anak usia dini atau anak usia prasekolah merupakan fase perkembangan individu sekitar 2-6 Tahun, pada saat ini seorang anak memiliki kesadaran tentang dirinya, mampu mengatur diri dalam buang air, dan mengenal beberapa hal yang dianggap berbahaya. ${ }^{15}$ Anak usia dini ini menuntut orang tua untuk benar-benar memiliki kemampuan akan pemahaman psikologi anak, karena pemahaman orang tua terhadap psikologi seorang anak akan membantu dalam perkembangan anak kearah yang positif.

Usia dini merupakan periode awal yang paling penting dan mendasar sepanjang rentang pertumbuhan serta perkembangan kehidupan manusia. Salah satu ciri masa usia dini adalah periode keemasan, dalam hal ini yaitu masa semua potensi anak berkembang paling cepat. ${ }^{16}$ Periode keemasan seorang anak tidak dapat diulang kembali apabila potensi-potensinya tidak distimulasi secara optimal dan maksimal pada usia dini tersebut, dan jika hal itu terjadi maka tahap perkembangan anak berikutnya akan terhambat.

Anak usia dini adalah individu yang unik yang memiliki pola pertumbuhan dan perkembangan fisik, kognitif, sosio-emosional, kreatifitas, bahasa, dan

\footnotetext{
${ }^{13}$ Joan Freeman, Utami Munandar, Cerdas Dan Cemerlang Kiat Menemukan Dan Mengembangkan Bakat Anak 0-5 Tahun, (Jakarta: PT Gramedia Pustaka Utama, 2001), hlm. 254-260.

${ }^{14}$ Ibid, Nurla, hlm. 96

${ }^{15}$ Ibid, Syamsu, Psikologi, (Bandung: PT Remaja Rosdakarya, 2014), hlm.162.

${ }^{16}$ Dadan Suryana \& Nenny Mahyudin, Dasar-Dasar Pendidikan TK, (Tangerang Selatan: Universitas Terbuka, 2014), hlm. 1.3.
} 
komunikasi yang khusus sesuai dengan tahapan yang sedang dilalui oleh anak tersebut. Sangat berbeda pola asuh yang diberikan seorang ibu yang memahami psikologi anak dengan pola asuh yang diberikan seorang ibu yang tidak memahami psikologi anak. Pada masa usia dini anak sering melakukan hal-hal yang diluar pikiran kita.

Menurut Eko Setiawan Pendidikan anak usia dini penting karena dasar hukum PAUD jelas, seperti yang terdapat dalam pembukaan UUD 1945 alinea keempat, amandemen UUD 1945 pasal 28C, UU No 23 tahun 2013 pasal 9 tentang perlindungan anak dan pasal 28 tentang sistem pendidikan nasional. Perhatian hukum ini berkembang seiring dipahaminya peran penting masa emas (golden age) pada rentang usia dini, bahwa; ${ }^{17}$

a. Karena perkembangan anak berlangsung secara berkesinambungan, perkembangan anak usia dini lebih kritis dibanding dengan perkembangan tahap berikutnya. Dengan demikian pendidikan anak usia dini penting bagi tahap perkembangan anak selanjutnya.

b. PAUD sebagai titik sentral strategi pembangunan sumber daya manusia dan berdampak terhadap keberlangsungan pembangunan masyarakat indonesia.

c. PAUD memegang peran penting dan menentukan bagi sejarah perkembangan anak tahap lanjut. Hal ini dikarekan PAUD membentuk fondasi dasar bagi kepribadian anak.

d. Anak yang mendapat pembinaan sejak dini akan mampu meningkatkan kesehatan dan kesejahteraan fisik maupun mental mereka. Dengan demikian anak akan lebih mandiri dan memiliki kemampuan dalam mengoptimalkan potensi yang dimiliki.

e. Usia dini merupakan masa usia keemasan, $80 \%$ perkembangan otak terjadi pada periode usia dini.

f. Periode usia dini merupakan cerminan keberhasilan anak dimasa yang akan datang.

Pendidikan anak usia dini mencakup tiga poin pokok menurut Hartoyo dalam Mansur diantaranya adalah; Pertama, pemberian upaya untuk menstimulasi, membimbing, mengasuh, dan pemberian kegiatan pembelajaran yang akan menghasilkan kemampuan dan keterampilan pada anak. Kedua, salah satu bentuk penyeleggaraan yang menitik beratkan pada peletakan dasar kearah pertumbuhan dan perkembangan fisik, kecerdasan, sosio emosional, bahasa, dan

\footnotetext{
${ }^{17}$ Eko Setiawan, Kompetensi Pedagogik \& ProfesionalGuru PAUD dan SD/MI, (TK: Erlangga, 2018), hlm. 14-16.
} 
Siti Hairiyah \& Mukhlis

komunikasi. Ketiga, penyesuaian dengan tahap-tahap perkembangan yang dilalui oleh anak usia dini. ${ }^{18}$

\section{Bermain}

Bermain adalah melakukan sesuatu dengan menyenangkan, dalam hal ini dapat di ketahui klasifikasi kegiatan bermain anak beragam macamnya diantaranya; bermain bebas dan spontan, bermain berpura-pura, bermain secara soliter, bermain secara paralel, bermain asosiatif, dan bermain secara kooperatif. ${ }^{19}$ Bermain sebagai pendekatan pembelajaran hendaknya disesuaikan dengan perkembangan usia dan kemampuan anak didik, yang secara berangsur-angsur perlu dikembangkan dari bermain sambil belajar menjadi belajar sambil bermain, dengan demikian dalam bermain harus memperhatikan kematangan dan tahap perkembangan anak didik, alat bantu atau alat permainan, metode yang digunkan, waktu dan tempat serta teman bermain.

Karakteristik bermain, dalam hal ini meliputi; Menyenangkan dan menggembirakan bagi anak, dorongan bermain muncul dari anak bukan paksaan orang lain, anak melakukan spontan dan suka rela, semua anak terlibat aktif secara bersama-sama, anak berlaku pura-pura tidak sungguhan, anak menetapkan aturan main sendiri (sesuai kebutuhan anak), anak berlaku aktif (bergerak dan berfikir), dan flesibel (Anak bebas memilih mau bermain apa dan beralih ke kegiatan bermain lain).

Fungsi bermain bagi anak diantaranya adalah: Pertama, anak akan lebih mudah memahami aritmatika jika diajarkan melalui bermain, karena dengan bermain anak akan mengalami langsung dan akan melekat dalam ingatannya secara kuat segala apa yang telah dimainkan. Kedua, anak akan melakukan kebiasaan bermainnya kelak ketika dewasa, oleh karena itu ketika anak bermain perlu diberikan motifasi dengan permainan yang dapat ditekuni dimasa selanjutnya. Ketiga, melatih anak untuk konsentrasi dan dapat membentuk belajar yang efektif karena dapat memberikan rasa senang sehingga dapat menimbulkan motifasi instrinsik anak untuk belajar. Keempat, dapat mengisi kembali energi seorang anak yang telah melemah. Kelima, mengekspresikan dorongan implusif sebagai cara untuk mengurangi kecemasan yang berlebihan pada anak. Keenam, mengaktifkan otak kanan, mengintegrasikan fungsi belahan otak kanan dan kiri

\footnotetext{
${ }^{18}$ Mansur, Pendidikan Anak Usia Dini dalam Islam, (Yogyakarta: Pustaka Pelajar, 2005), hlm. 89.

${ }^{19}$ Masitoh, Strategi Pembelajaran TK, (Tangerang selatan: Universitas Terbuka, 2014), hlm. 9.1.
}

272 | Kariman, Volume 07, Nomor 02, Desember 2019 
secara seimbang dan membentuk struktur saraf, serta mengembangkan pilar-pilar saraf pemahaman yang berguna untuk masa mendatang. ${ }^{20}$

Dengan kita mengetahui fungsi dari bermain maka kita dapat mengetahui pula bahwa bermain memberikan banyak manfaat, baik terhadap anak secara langsung ataupun terhadap orang tua. Dengan demikian dapat diuraikan bahwa tujuan dan manfaat bermain meliputi; Mendapat kesempatan untuk mengembangkan diri, dapat bersosialisasi, untuk melepaskan diri dari ketegangan, sebagai dasar pertumbuhan mentalnya, dapat mngembangkan imajinasinya seluas mungkin, dapat berpetualang menjelajah lingkungan dan menemukan hal-hal baru dalam kehidupan, untuk belajar bekerjasama, mengerti peraturan, saling berbagi, belajar menolong diri sendiri dan orang lain, serta menghargai waktu, untuk mengembangkan kreatifitas anak, untuk Mengembangkan keterampilan olahraga dan menari, dan untuk melatih konsentrasi perhatian terhadap sesuatu.

Faktor- faktor yang mempengaruhi perbedaan anak dalam bermain, Menurut elizabet Hurlock dalam hal ini terdapat 6 factor diantaranya adalah; ${ }^{21}$ kesehatan, perkembangan Motorik, intelegensi, jenis Kelamin dan taraf social ekonomi, dan alat permainan.

\section{Permainan Edukatif}

Permainan edukatif adalah semua bentuk permainan yang dirancang untuk memberikan pengalaman pendidikan atau pengalaman belajar kepada para pemainnya. Permainan atau pengalaman edukatif dapat memotivasi anak senang belajar, semisal kita ingin menjelaskan kehidupan dan kekayaan satwa Indonesia maka sebaiknya kita membawa anak didik ke kebun binatang atau wisata alam, agar mereka terlibat langsung serta dapat melihat dan belajar secara nyata yang nantinya akan menjadi pengalaman edukatif bagi anak. ${ }^{22}$

Ciri alat permainan edukatif adalah; Alat permainan ditujukan untuk anak usia dini, difungsikan untuk mengembangkan berbagai perkembangan anak usia dini, digunakan dengan berbagai cara, bentuk, dan untuk bermacam tujuan aspek perkembangan, aman tidak berbahaya bagi anak, dirancang untuk mendorong aktifitas dan kreatifitas anak, bersifat konstruktif (ada sesuatu yang dihasilkan), dan mengandung nilai pendidikan. ${ }^{23}$

\footnotetext{
${ }^{20}$ Ibid, Mohammad, hlm. 12-15.

${ }^{21}$ Elizabeth Hurlock, dalam https:/www.paud.id, Paud Jateng, (28 september, 2015).

${ }^{22}$ Agung Triharso, Permainan Kreatif \& Edukatif Untuk Anak Usia Dini, (Yogyakarta: ANDI, 2013), hlm. VI.

${ }^{23}$ Deddy Sofyandi, Ciri-Ciri Mainan Edukatif, https:// kayu-seru.com Posted on 05/09/2016. Diakses 20 N0vember 2019.
} 
Siti Hairiyah \& Mukhlis

Dengan adanya alat permainan edukatif tentunya proses pembelajaran akan lebih efektif dan efisien, apalagi dalam dunia pendidikan anak usia dini pembelajaran berlangsung sambil bermain. Dalam hal ini dapat diketahui bahwa bahwa tujuan alat permainan edukatif adalah; Memperjelas materi yang diberikan, memberikan motifasi dan merangsang anak untuk bereksplorasi dan bereksperimen dalam mengembangkan berbagai aspek perkembangannya, dan memberikan kesenangan pada anak dalam bermain.

Selain memiliki tujuan yang jelas alat permainan edukatif juga memiliki fungsi yang cukup berarti dalam proses pembelajaran, yakni; Menciptakan situasi bermain (belajar) yang menyenangkan bagi anak dalam proses pemberian perangsangan indicator kemampuan anak, menumbuhkan rasa percaya diri dan membentuk citra diri anak yang positif, memberikan stimulus dalam pembentukan perilaku dan pengembangan kemampuan dasar, memberikan kesempatan anak bersosialisasi, berkomunikasi dengan teman sebaya.

Terdapat beberapa alasan betapa pentingnya pengembangan alat permainan edukatif; Pertama, dengan perkembangan zaman, dan banyaknya hasil penelitian yang menunjukkan bahwa IQ menentukan keberhasilan anak hanya sekitar 20\%, sementara $80 \%$ ditentukan oleh factor eksternal. Kedua, sistem pendidikan yang lebih menekankan pada pengembangan belahan otak kiri (unsur kognitif; logika, matematika, berfikir sistematis, dan lain-lain) tanpa diimbangi dengan pengembangan belahan otak kanan (seni, music, berfikir holistic, keterampilan berbahasa, kreatifitas, imajinasi, dan lain-lain) tidaklah mencukupi, malah bisa membuat anak stress. Ketiga, teori multiple intelegence menyebutkan bahwa kecerdasan tidak hanya berupa kemampuan untuk menyelesaikan tugas-tugas di sekolah yang lebih banyak kaitannya dengan kemampuan verbal logis, akan tetapi kecerdasan adalah kumpulan kemampuan yang dimiliki seseorang untuk memahami informasi, mengumpulkan fakta, dan menyampaikan pengetahuan yang didapatnya. Keempat, dengan mengetahui berbagai jenis permainan orang tua atau guru dapat mengaplikasikan dalam kehidupan sehari-hari bersama anak.

\section{Pengembangan Kreatifitas Anak Usia Dini Melalui Permainan Edukatif}

Pengembangan kreatifitas adalah serangkaian aktifitas yang dilakukan dengan sengaja untuk berlangsungnya perubahan-perubahan agar anak memiliki kemampuan untuk berbuat sesuatu yang baru. Kreatifitas seseorang dapat dilihat dari adanya tindakan-tindakan yang bersifat baru. Pengembangan kreatifitas dapat berjalan dengan baik melalui proses penemuan dan pencarian, karena dengan 
demikian anak akan mencoba-coba atau meneliti dengan menggunakan ide-ide atau cara-cara baru dengan alat dan bahan yang sederhana.

Anak usia dini pada hakikatnya adalah anak-anak yang kreatif dan sangat suka bereksperimen, karena hanya dengan pengalaman mereka belajar untuk merencanakan dan mengembangkan cara-cara melakukan sesuatu. Untuk mengembangkan kreatifitas seorang anak perlu diawali dengan mengembangkan bakat alami anak, yakni melalui serangkaian aktifitas yang kreatif. Menurut Ken Adams permainan kreatif meliputi; ${ }^{24}$ Menggambar, mewarnai, dan melukis, menggunting, koleksi, kolase, membuat tiruan bentuk, merancang bangunan, dan bermain peran dan imajinasi.

Pengembangan kreatifitas dapat dilakukan oleh orang tua dalam kehidupan sehari-hari di rumah, dalam hal ini tentunya orang tua bisa melakukan beberapa hal yang bisa membantu dalam menumbuhkan kreativitas anak. Dalam hal ini dapat dilakukan melalui empat pendekatan, diantaranya; Pertama, Pribadi, tindakan kreatif muncul dari keunikan keseluruhan kepribadian dalam interaksi dengan lingkungan. Kedua, Proses, langkah-langkah proses kreatif dimulai dari tahap persiapan (inkubasi, iluminasi, verivikasi). Ketiga, Dorongan, berupa dorongan internal dan eksternal dari lingkungan sosial dan psikologis. keempat, Hasil akhir, yang ditandai dengan orisinalitas, pembaharuan, kebermaknaan, dan teramati.

Empat hal yang perlu dilakukan dalam proses pembelajaran agar dapat mengembangkan kreatifitas anak; ${ }^{25}$

a. Mengembangkan rasa percaya diri pada anak dan tidak menimbulkan adanya perasaan takut.

b. Memberi kesempatan untuk menyampaikan keinginannya secara bebas dan terarah.

c. Memberikan pengawasan yang tidak terlalu ketat dan tidak otoriter.

d. Melibatkan secara aktif dan kreatif dalam proses pembelajaran secara keseluruhan.

Pada setiap pelaksanaan proses pembelajaran sesungguhnya bertujuan untuk mengembangkan aktifitas dan kreatifitas anak didik yakni dengan berbagai interaksi dan pengalaman belajarnya. Akan tetapi seringkali dalam

\footnotetext{
${ }^{24}$ Kens Adam, Semua Anak Jenius, Aktivitas Seru Untuk Mengembangkan Kecerdasan Anak usia 0-11 tahun, (London: Erlangga, 2006), hlm.82-83.

${ }^{25}$ E. Mulyasa, Menjadi Guru Profesional Menciptakan Pembelajaran Kreatif dan Menyenangkan, (Bandung: PT Remaja Rosdakarya, 2015), hlm. 165.
} 
Siti Hairiyah \& Mukhlis

pelaksanaannya tidak disadari bahwa masih sering terjadi kegiatan pembelajaran yang justru menghambat aktifitas dan kreatifitas anak didik. Oleh karena itulah dalam proses pembelajaran khususnya pendidikan anak usia dini yang begitu memiliki peran penting dalam menentukan perkembangan dan kepribadian anak, kegiatan pembelajaran harus mampu mengembangkan aktifitas dan kreatifitas seorang anak. Pemebelajaran dalam pendidikan anak usia dini merupakan pembelajaran sambil bermain, dalam hal ini permainan-permainan yang dimainkan harus sesuai dengan tujuan pembelajaran yang ingin dicapai.

Permainan edukatif yang dapat dilakukan dalam mengembangkan kreatifitas anak usia dini adalah; ${ }^{26}$

1. Permainan drama, misalnya bermain dokter-dokteran entah anak yang berperan sebagai dokter atau pasien dengan ini anak akan mulai mngembangkan pikirannya dalam bersosialisasi dan berekspresi.

2. Permainan seni alam, dalam hal ini misalnya membuat bentuk wajah dari lumpur di batang pohon, membuat menara dari ranting-ranting, membuat miniatur taman dengan memanfaatkan rumput, ranting, tanah, d1l, membuat pewarna alami dari kunyit, dan lain-lain.

3. Bermain rumah-rumahan, selama permainan berlangsung anak diberikan kebebasan penuh untuk menunjukkan kemampuan dan keinginan dirinya.

4. Permainan Karya wisata, anak-anak dapat belajar dari pengalaman langsung dan akan mentransfer pengetahuannya dilain waktu.

Menurut Rubiyar, banyak benda-benda bekas yang dapat digunakan sebagai alat permainan edukatif. Dan banyak juga permainan edukatif yang bisa dilakukan bersama anak-anak, diantaranya adalah; robot, roda tarik, batik celup, balingbaling dorong, boneka tangan kucing, sandal fantasi, lampion tekuk, baling-baling tarik 1, 2, dan 3, merangkai bentuk geometri, lampion kubus, rantai kertas, kreasi kertas remas, meja dan kursi, boneka layang, kerangka ikan, kincir gantung, meronce kertas, baling-baling tiup, kupu-kupu, boneka pensil, membuat puzzle, boneka sapi, boneka stik es, boneka kerucut, rantai segitiga, ikan pancing, dan merangkai tutup botol. ${ }^{27}$

Permainan-permainan yang akan dilakukan harus disesuaikan dengan usia dan kemampuan anak karena tidak semua permainan dapat dimainkan oleh anak. Permainan kreatif harus menggunakan mainan yang menunjukkan tentang sesuatu yang sesungguhnya yakni; boneka, mobil, kereta, orang-orangan, kantor polisi,

\footnotetext{
${ }^{26}$ Clare Ford, 100 Ide untuk guru paud membimbing anak siap sekolah, (TK: Erlangga, 2016), hlm. 90.

${ }^{27}$ Rubiyar, 30 Kreasi Mainan Edukatif Untuk Buah Hati, (Surabaya: Tiara Aksara, 2007), hlm. 4-74.
}

276 | Kariman, Volume 07, Nomor 02, Desember 2019 
stasiun pemadam kebakaran, peralatan perawat, pakaian berdandan, dan lain-lain. Dalam permainan imajinatif dapat menggunakan apa saja yang ada di sekitar anak, seperti; papan, radio, batu, ranting-ranting, balok, plastik, tanah liat, dan lain-lain. Dengan memberikan sebuah mainan kepada anak berarti telah mengenalkan sesuatu yang baru, baik dari segi bentuknya, cara memainkannya, dan manfaat mainan tersebut.

Anak-anak yang sudah mulai berfikir kreatif di usia dini dapat menjalani pembelajaran dengan percaya diri dan penuh imajinasi. Rasa percaya diri anak bisa hilang dengan kesalahan yang dibuatnya, banyak anak yang merasa senang ketika ia bisa langsung benar saat melakukan suatu kegiatan akan tetapi mereka kesulitan menerima kenyataan jika ia salah saat melakukan kegiatan. Dengan ini berikan pemahaman sebaik mungkin pada anak bahwa kesalahan yang kita perbuat dapat kita jadikan pelajaran untuk langkah berikutnya. Pada saat kita bermain dengan seorang anak, penting juga untuk membelajarkan pada anak tentang cara menyesuaikan perilaku mereka berdasarkan tempat mereka, anakanak dapat berlarian, berteriak dan lain sebagainya pada suatu waktu, namun diwaktu lain perlu duduk dan mendengarkan.

Dengan adanya pernyataan tersebut maka ketika anak bermain sebaiknya menggunakan alat permainan edukatif agar anak memperoleh sesuatu yang bernilai pendidikan dalam proses bermainnya. Pengengbangan kreatifitas penting untuk dikembangkan semaksimal mungkin karena perkembangan kreatifitas berkaitan dan menjadi penentu dalam mengembangkan aspek-aspek perkembangan lainnya. Perkembangan kreatifitas erat kaitannya dengan kecerdasan majemuk, menurut Howard Gardner dalam Igrea kecerdasan majemuk meliputi; kecerdasan Spatial, Linguistic, Intrapersonal, Musical, Naturalist, Bodily, Interpersonal, Logical Mathematical, dan Spiritual. ${ }^{28}$ Strategi pengembangan kreatifitas anak usia dini menurut E Mulyasa dapat dilakukan melalui berbagai hal, diantaranya adalah; ${ }^{29}$ karya nyata, imajinasi, eksplorasi, Eksperimen, proyek, musik, dan bahasa, dengan melakukan kegiatan-kegiatan tersebut maka anak akan dapat mengembangkan kreatifitasnya.

Menurut Tuhana Taufiq Andrianto ada dua faktor yang dapat menentukan keberhasilan pengembangan kreatifitas seseorang, Pertama, faktor internal yakni; pemberian nutrisi yang baik, pelatihan-pelatihan kreatifitas, mengembangkan

\footnotetext{
${ }^{28}$ Igrea Siswanto dan Sri Lestari, Pembelajaran Atraktif dan 100 Permainan Kreatif untuk PAUD, (Yogyakarta: C.V ANDI Offset, TT), hlm. 122-123.

${ }^{29}$ E. Mulyasa, Manajemen PAUD, (Bandung: PT Remaja Rosdakarya, 2014), hlm. 103-116.
}

Kariman, Volume 07, Nomor 02, Desember 2019|277 
Siti Hairiyah \& Mukhlis

menjadi individu pembelajar, dan pembentukan paradigma lokus kendali. Kedua, faktor eksternal yakni; penciptaan lingkungan kreatif. Dengan demikian dapat disimpulkan bahwa pengembangan kreatifitas bisa dilakukan melalui mengembangkan faktor internal dan eksternal yang kreatif, yakni; ${ }^{30}$

\begin{tabular}{|c|c|c|}
\hline $\begin{array}{l}\text { Mengembangkan } \\
\text { Faktor Eksternal } \\
\text { Yang kreatif }\end{array}$ & $\begin{array}{l}\text { Mengembangkan } \\
\text { Faktor Internal } \\
\text { Yang kreatif }\end{array}$ & Kreativitas \\
\hline $\begin{array}{l}\text { - } \text { Mengembangkan daya } \\
\text { pikir dengan membaca } \\
\text { - Mengembangkan kualitas } \\
\text { cara berfikir } \\
\text { - Menggeluti tekhnologi } \\
\text { - Menggemari kesenian } \\
\text { - Membebaskan diri dari } \\
\text { alam kesadaran lain } \\
\text { - Menyatu dengan jiwa } \\
\text { kreatif }\end{array}$ & $\begin{array}{l}\text { - } \text { Menyatu dengan } \\
\text { masyarakat } \\
\text { - Mengembara, studi } \\
\text { banding, dan wisata. } \\
\text { - Mengembangkan } \\
\text { suasana kondusif / } \\
\text { menyenangkan. }\end{array}$ & $\begin{array}{l}\text { - Kebaruan internal } \\
\text { - Kebaruan eksternal } \\
\text { - Kebaruan dunia } \\
\text { - Kombinasi } \\
\text { - Variasi } \\
\text { - Kemanfaatan }\end{array}$ \\
\hline
\end{tabular}

Menurut Mohammad Takdir Ilahi pengembangan kreatifitas anak memiliki kaitan erat dengan pola asuh demokratis orang tua. Dalam hal ini dapat dipelajari bersama tentang orang tua yang menerapkan pola asuh demokratis yakni; ${ }^{31}$ Pertama, cendrung menempatkan anak sebagai pribadi yang penting dalam segala persoalan. Kedua, cendrung bersikap menghargai usaha, kinerja, dan prestasi anak dengan penuh kebanggaan. Ketiga, selalu memberikan keteladanan yang baik terhadap anak-anak mereka. Keempat, cendrung mendorong anak untuk bersikap disiplin dalam setiap aktifitasnya.

Dari beberapa penjelasan sebelumnya menunjukkan bahwa pengembangan kreatifitas anak dapat dilakukan melalui permainan edukatif, pola asuh orang tua demokratis, dan juga pendampingan orang tua dalam membantu mengembangkan anak kreatif. Pendidikan anak usia dini merupakan waktu yang sangat tepat untuk mengembangkan kreatifitas, oleh sebab itulah dibutuhkan adanya program-

\footnotetext{
${ }^{30}$ Tuhana Taufiq Andrianto, Cara Cerdas Melejitkan IQ Kreatif Anak, (Jogjakarta: KATAHATI, 2013), hlm. 137221.

${ }^{31}$ Mohammad Takdir Ilahi, Quantum Parenting Kiat Sukses Mengasuh Anak Secara Efektif dan Cerdas, (Jogjakarta: Kata Hati, 2013), hlm. 140-142.
}

278 | Kariman, Volume 07, Nomor 02, Desember 2019 
Siti Hairiyah \& Mukhlis

program permainan dan pembelajaran yang dapat memelihara dan mengembangkan potensi kreatif anak.

Penting sekali kreatifitas seorang anak dikembangkan karena kreatifitas merupakan keterampilan utama yang diperlukan untuk mencapai sesuatu, mencapai perubahan, perbaikan, dan arah tujuan yang baru. Menggunakan dan memperaktikkan kreatifitas adalah cara terbaik untuk mengembangkan keterampilan dan kebiasaan mental agar bisa berfikir kreatif.

\section{Kesimpulan}

Pengembangan kreatifitas merupakan sebuah usaha yang dilakukan orang tua di rumah atau guru di sekolah dengan sengaja untuk membantu anak dalam berfikir, berkreasi, atau beraktifitas untuk dapat menujukkan kemampuann dirinya. Pengembangan itu penting dilakukan agar anak memiliki kebebasan untuk berimprofisasi dan berkreasi sesuai dengan keinginan dan kemampuannya masing-masing. Dalam pembelajaran hendaknya dilakukan secara efektif, efisien, produktif, dan akuntabel, dengan demikian maka perlu adanya perencanaan, pelaksaan, monitoring, dan evaluasi secara berkesinambungan, proporsional, dan profesional.

Anak usia dini merupakan individu yang sedang mengalami proses pertumbuhan dan perkembangan yang sangat pesat. Segala aktifitas anak usia dini memiliki unsur bermain, baginya bermain lebih efektif dan menyenangkan serta akan memudahkan dalam memahami sesuatu karena tanpa ia sadari dengan bermain ia dapat mengetahui dan mngingat suatu hal.

Permainan edukatif merupakan serangkaian permainan yang memiliki nilai pendidikan, ada banyak permainan edukatif yang dapat dilakukan oleh guru di sekolah atau oleh orang tua di rumah. Salah satu permainan edukatif diantaranya; Permainan drama, seni alam, rumahrumahan, karya wisata, dan lain-lain.

Pengembangan kreatifitas anak usia dini melalui permainan edukatif ini perlu dilakukan oleh orang tua di rumah atau guru di sekolah, karena permainan edukatif mampu memberikan konstribusi yang baik dalam pengembangan segala aspek perkembangan anak. 
Siti Hairiyah \& Mukhlis

\section{DAFTAR PUSTAKA}

Adam Kens, Semua Anak Jenius, Aktivitas Seru Untuk Mengembangkan Kecerdasan Anak usia 0-11 tahun, London: Erlangga, 2006.

A Partanto Pius dan M Dahlan Al Barry, Kamus Ilmiah Populer, Surabaya: Arkola, 2001.

Aunillah Nurla Isna, Membentuk Karakter Anak, Yogyakarta: FlashBooks, 2015.

Andrianto Tuhana Taufiq, Cara Cerdas Melejitkan IQ Kreatif Anak, Jogjakarta: KATAHATI, 2013.

Bono E. de., Metode Mencetuskan Ide-Ide Cerdas, Orisinal, dan Kreatif, Jogjakarta: tHink, 2008.

Desmita, Psikologi Perkembangan Peserta Didik Panduan Bagi Orang Tua dan Guru Dalam Memahami Psikologi Anak Usia SD, SMP, dan SMA, Bandung: PT Remaja Rosdakarya, 2014.

E. Mulyasa, Menjadi Guru Profesional Menciptakan Pembelajaran Kreatif dan Menyenangkan, Bandung: PT Remaja Rosdakarya, 2015.

E. Mulyasa, Manajemen PAUD, Bandung: PT Remaja Rosdakarya, 2014.

Fauziddin Mohammad, Pembelajaran PAUD Bermain, Cerita, dan Menyanyi Secara Islami, Bandung: PT REmaja Rosdakarya, 2014.

Freeman Joan, Munandar Utami, Cerdas Dan Cemerlang Kiat Menemukan Dan Mengembangkan Bakat Anak 0-5 Tahun, Jakarta: PT Gramedia Pustaka Utama, 2001.

Ford Clare, 100 Ide untuk guru paud membimbing anak siap sekolah, TK: Erlangga, 2016.

http://paud-anakbermainbelajar.blogspot.com/. Diakses tgl 20 November 2019. Hurlock Elizabeth, dalam https:/www.paud.id, Paud Jateng, 28 september, 2015. Mansur, Pendidikan Anak Usia Dini dalam Islam, Yogyakarta: Pustaka Pelajar, 2005. Masitoh, Strategi Pembelajaran TK, Tangerang selatan: Universitas Terbuka, 2014. Rahman Hibana S, Konsep Dasar Pendidikan Anak Usia Dini, Yogyakarta: PGTKI Press, 2005.

Rubiyar, 30 Kreasi Mainan Edukatif Untuk Buah Hati, Surabaya: Tiara Aksara, 2007.

Setiawan Eko, Kompetensi Pedagogik \& ProfesionalGuru PAUD dan SD/MI, TK: Erlangga, 2018.

Seto Kak, Bermain dan Kreatifitas, Jakarta: Papas Sinar Sinanti, 2004. 
Siti Hairiyah \& Mukhlis

Siswanto Igrea dan Sri Lestari, Pembelajaran Atraktif dan 100 Permainan Kreatif untuk PAUD, Yogyakarta: C.V ANDI Offset, TT.

Sofyandi Deddy, Ciri-Ciri Mainan Edukatif, https:// kayu-seru.com Posted on 05/09/2016. Diakses 20 N0vember 2019.

Sujiono Yuliani Nurani. Dkk, Metode Pengembangan Kognitif, Tangerang Selatan: Universitas Terbuka, 2013.

Suryana Dadan \& Nenny Mahyudin, Dasar-Dasar Pendidikan TK, Tangerang Selatan: Universitas Terbuka, 2014.

Takdir Ilahi Mohammad, Quantum Parenting Kiat Sukses Mengasuh Anak Secara Efektif dan Cerdas, Jogjakarta: Kata Hati, 2013.

Triharso Agung, Permainan Kreatif \& Edukatif Untuk Anak Usia Dini, Yogyakarta: ANDI, 2013.

Yusuf LN Syamsu, Psikologi Perkembangan Anak \& Remaja, Bandung: PT Remaja Rosdakarya, 2014.

Zaman Badru, dalam https:/www.asik belajar.com diakses tgl 20 November 2019. 
Siti Hairiyah \& Mukhlis

282 | Kariman, Volume 07, Nomor 02, Desember 2019 